\title{
Effect of Crop Establishment Techniques and N Levels of Rice on SYSTEM Productivity and Economics of Rice- Greengram System
}

\author{
P. Amara Jyothi ${ }^{1 *}$, M. Martin Luther ${ }^{2}$, A. Upendra Rao ${ }^{3}$ and B. Mounika ${ }^{4}$ \\ ${ }^{1}$ SMS, Crop Production, KVK, Amadalavalasa, Srikakulam, India \\ ${ }^{2}$ Agronomy, Agricultural college, Bapatla, India \\ ${ }^{3}$ Agronomy, Agricultural College, Naira, India \\ ${ }^{4} \mathrm{SMS}$, Agrometeorology, KVK, Amadalavalasa, Srikakulam, India
}

*Corresponding author

\section{Keywords}

Rice, Crop establishment techniques, $\mathrm{N}$ levels

\section{Article Info}

Accepted:

15 May 2020

Available Online:

10 June 2020
A field experiment was conducted for two consecutive years 2015-16 and 2016-17 at Agricultural Research station, Ragolu, Srikakulam, Andhra Pradesh, with four establishment techniques as main plots and five nitrogen levels as sub plots in a split plot design on sandy clay loam soil. The study revealed that crop establishment technique planting with machine recorded significantly higher values of system productivity of rice-greengram. Application of $210 \mathrm{~kg} \mathrm{~N}^{-1}$ to rice recorded the maximum system productivity of rice-greengram system during both the years of study.

\section{Introduction}

India has the largest area among rice growing countries and stands second in production. In India, rice is grown in an area of 44.1 million hectares with a production of 108.9 million tonnes and productivity of $2391 \mathrm{~kg}$ ha-1. In Andhra Pradesh, it is grown in an area of 2.4 million hectares with a production of 7.24 million tonnes and productivity of $3022 \mathrm{~kg}$ ha 1 (Ministry of Agriculture, Government of India, 2016-17). Projection of India's rice production target for 2025 A.D is 140 million tonnes per year and this need to be achieved against the back drop of plateauing of rice yields coupled with restrictions on area expansion, diminishing natural resources such as land and water (Sridhara et al., 2011).

Growing more rice with reduced cost of production and maintaining soil health are the major concerns of rice farming Traditional flooded rice cultivation has increasingly experienced shortages in irrigation water, labour and higher labour wages. In addition to high water requirement, the traditional system 
of transplanted rice production on puddled soil influences the soil aeration and reduces yields of post sequence crops.

These factors have adversely affected the farm operations and profits of rice based cropping systems. Rice growers across the country seek elevated levels of productivity to counter balance ever increasing cost of production. These conditions emphasize the need for shift to labour and water saving rice cultivation methods, which can shorten the duration of crop and increase yields.

Good crop establishment is one of the vital components for efficient use of resources and desired level of productivity in rice. In order to reduce the manpower requirement and cost of production, a need has been felt to replace the manual transplanting with some scientifically sound, technically feasible, economically viable and environmentally safe establishment technique (Sanjay et al., 2006).

Direct seeding of dry seed, Drum seeding, aerobic rice and planting with machine transplanter are some of the methods of crop establishment which may ensure better plant population and less reliant on labour compared to conventional practice of manual transplanting (Mankotia et al., 2009) and are gaining popularity among the farmers with the advent of highly efficacious herbicides.

Rice-greengram system is one of the predominant cropping systems of Andhra Pradesh and there is no adequate information on the residual effect of nitrogen fertilization to different systems of rice establishment on succeeding crops particularly greengram with reference to productivity and dynamics of soil fertility.

\section{Materials and Methods}

The present investigation was conducted during 2015-16 and 2016-17 at Agricultural
Research Station, Ragolu in North coastal agro climatic zone of Andhra Pradesh, situated at 180.24 ' $\mathrm{N}$ latitude, $830.84^{\prime} \mathrm{E}$ longitude and at an altitude of $27.0 \mathrm{~m}$ above the mean sea level. The experimental soil was sandy clay loam in texture, neutral in reaction, low in organic carbon, low in available nitrogen, medium in available phosphorus and potassium. The experiment was laid out in a split plot design, replicated thrice with four crop establishment techniques as main plots and five nitrogen levels as sub plots. The main plot treatments consisted of (i) Dry direct sown rice (ii) Aerobic rice (iii) Planting with machine and (iv) Normal planting. The subplot treatments consisted of five nitrogen levels (90, 120, 150, 180 and $210 \mathrm{~kg} \mathrm{~N}$ ha1 ). The cultivar used in the study for rice was MTU 1001(vijetha). Nitrogen in the form of urea was applied as per the treatments in three equal splits as one third basal, one third at active tillering and one third at panicle initiation stage. A common dose of $60 \mathrm{~kg} \mathrm{P} 2$ $\mathrm{O} 5$ and $50 \mathrm{~kg}$ K2 O ha-1 was applied uniformly through single super phosphate and muriate of potash, respectively. Entire dose of phosphorus was applied as basal. Whole potassium was applied in 2 splits as basal and $1 / 3$ at panicle initiation stage along with urea. A common dose of $\mathrm{ZnSO} 4$ @ 20 kg ha1 was applied to all the treatments uniformly as basal. The sowing of dry direct sown rice (DDS rice) and aerobic rice was done in lines in the non puddled and non flooded soil at a spacing of $20 \times 10 \mathrm{~cm}$. Nursery was raised in trays for planting with machine technique on the same day of sowing of dry direct sown rice and aerobic rice. Tray nursery was used to suit mechanical transplanting. Seedlings from tray nursery of 14 days age were machine transplanted to ensure uniform depth and seedlings per hill at a spacing of $30 \mathrm{~cm} \mathrm{x}$ $18 \mathrm{~cm}$. Nursery was raised on thoroughly puddled and levelled nursery bed for normal planting method of establishment, on the same day of sowing of dry direct sown rice 
and aerobic rice. Nursery was raised upto the age of 25 days and transplanted manually at a spacing of $20 \mathrm{~cm} \times 15 \mathrm{~cm}$. In direct seeded rice and transplanting rice, weeds were controlled by applying pendimethalin @ 2.5 litres ha-1 within 2 days of sowing and transplanting of rice and bispyribac sodium @ $250 \mathrm{ml}$ ha- 1 at 30 days after sowing and 25 days after transplanting of rice, respectively. The left over weeds were removed by 2 hand weedings in direct seeded rice techniques and 1 hand weeding in transplanted rice techniques respectively. The observation on growth parameters viz., plant height, drymatter production and yield attributes viz., number of productive tillers $\mathrm{m}-2$, number of grains per panicle, filled grains per panicle, test weight, grain yield, straw yield and harvest index were analysed by using standard procedures.

The performance of succeeding greengram as influenced by different crop establishment techniques and N-levels was studied. The seeds of greengram cultivar LGG 460 (@ 30 $\mathrm{kg} \mathrm{ha}{ }^{-1}$ ) were broadcasted in standing rice crop 3 days before harvesting of rice as a relay crop during 2015-16 and 2016-17. Before broadcasting, greengram seed was treated with dithane M-45@2.5 g kg${ }^{-1}$ seed to protect the crop from diseases up to $20-25$ days after sowing. Overall, the crop was free from insect pest and diseases, however, a minor incidence of YMV was observed on LGG 460 at flowering stage during both the years of study. The spread of YMV was controlled by controlling the disease transmitting vector i.e., whitefly by spraying acephate@ $1 \mathrm{~g} \mathrm{~L}^{-1}$. The crop was harvested at physiological maturity stage. Plants from the border rows of each plot were harvested first and separated as bulk. Later, net plot area was harvested and dried in sun after separating the plants designated for recording biometric observations. The harvested crop from each net plot was bundled, tagged, weighed and transported to threshing floor. Threshing was done plot-wise and seeds were cleaned, dried and weighed separately for each net plot.

\section{Results and Discussion}

\section{Rice grain equivalent yield of greengram}

Rice grain equivalent yield of Greengram in rice-greengram sequence was significantly influenced by both crop establishment techniques and nitrogen levels of preceeding rice crop during both the years and the interaction effect of crop establishment techniques and nitrogen levels of preceding rice on rice grain equivalent yield of succeeding greengram was non-significant during both the years( Table -1).

The highest rice grain equivalent yield of Greengram was recorded in aerobic system of rice establishment $\left(2924,2769 \mathrm{~kg} \mathrm{ha}^{-1}\right.$ during 2015-16 and 2016-17 respectively) which was significantly higher over the machine transplanted rice and comparable with that of normal transplanting and DDS rice during both the years of study. The Rice grain equivalent yield of Greengram was significantly lowest in machine planted rice over other crop establishment techniques.

Direct seeded rice matures 1-2 weeks earlier than transplanted rice thus reducing the risk of terminal drought, allowing earlier sowing of succeeding crop and prevailing of aerobic system is the probable reason for higher Rice grain equivalent yield of Greengram in aerobic and DDS of rice establishment. Similar results are also reported by Mahanthy et al., (2014), Samanth and Patra (2016). During both the years, there was a progressive increase in Rice grain equivalent yield of succeeding green gram with the increase in nitrogen levels applied to the preceeding rice crop in the sequence. Among $\mathrm{N}$ levels the highest Rice grain equivalent yield of 
Greengram was recorded with $210 \mathrm{~kg} \mathrm{ha}^{-1}$, however the difference in seed yield between the $\mathrm{N}$ levels was measurable up to application of $\mathrm{N} @ 120 \mathrm{~kg} \mathrm{ha}^{-1}$ only and further increse in $\mathrm{N}$ level did not augment the grain yield conspicuously.

Whereas the seed yield was lowest with the application of N@90 kg ha ${ }^{-1}$. The favourable performance of residual effect of fertilisers might be due to prolonged availability of nutrients in such treatments. Similar results are also reported by Rani and $\operatorname{Rao}(2012)$, Prathibhasree et al., (2016) .

\section{System productivity}

Two crops viz., rice and green gram raised in a sequence during kharif and rabi were influenced significantly by different crop establishment techniques and $\mathrm{N}$ levels during both the years of study. The performance of this cropping system under the influence of crop establishment techniques and nitrogen levels could be assessed by summing of the performance of individual crops in each year so as to compare varied crop establishment techniques and $\mathrm{N}$ levels in rice green gram system as a whole.

Among the establishment techniques, maximum system productivity of ricegreengram was recorded in machine transplanting technique $\left(9231,9469 \mathrm{~kg} \mathrm{ha}^{-1}\right.$ during 2015-16 and 2016-17 respectively) and it was on a par with DDS and normal planting (Table.1). The lowest system productivity of rice-greengram was recorded in aerobic rice technique (8207, $8414 \mathrm{~kg} \mathrm{ha}^{-1}$ during 2015-16 and 2016-17 respectively). Better performance of rice-green gram system under planting with machine technique was mainly due to higher yields of both rice and greengram crops in the system. Murthy et al.,
(2015) reported superior performance of alternate systems of rice establishment on productivity of rice pulse system. Similar findings of superior performance of DDS rice- greengram system and machine planted rice-greengram systems over other rice establishment methods has been reported by Rao et al., (2016).

System productivity of rice-greengram increased with increase in level of nitrogen. Maximum system productivity of ricegreengram system was recorded with $210 \mathrm{~kg}$ $\mathrm{N} \mathrm{ha}^{-1}\left(9723,9986 \mathrm{~kg} \mathrm{ha}^{-1}\right.$ during 2015-16 and 2016-17 respectively) and it was on par with $180 \mathrm{~kg} \mathrm{~N} \mathrm{ha}{ }^{-1}$ and $150 \mathrm{~kg} \mathrm{~N} \mathrm{ha}{ }^{-1}$ and significantly superior to other lower levels of nitrogen during both the years of study (Table.2).

\section{Economics}

Varied crop establishment techniques and nitrogen levels followed in rice crop influenced the economics of rice-green gram system as a whole during both the years of study. The results revealed that maximum gross returns was recorded in the machine transplanted rice-greengram sequence (143266 , 151895 Rs. ha ${ }^{-1}$ during 2015-16 and 2016-17 respectively), which was however comparable with normal planting ricegreengram and significantly superior over DDS rice-greengram and aerobic ricegreengram. The lowest gross returns were recorded with aerobic rice-greengram sequence during both the years of study (Table 2). Among N levels, application of 210 $\mathrm{Kg} \mathrm{N}$ ha $^{-1}$ recorded maximum gross returns (150702,159881 Rs. ha ${ }^{-1}$ during 2015-16 and 2016-17 respectively) and it was on par with 180 and $150 \mathrm{~kg} \mathrm{~N} \mathrm{ha}^{-1}$ and significantly superior to other lower levels (90 and $120 \mathrm{~kg}$ $\mathrm{N} \mathrm{ha}{ }^{-1}$ ) during both the years of study. 
Table.1 System productivity $\left(\mathrm{kg} \mathrm{ha}^{-1}\right)$ of rice - greengram system as influenced by crop establishment techniques and nitrogen levels in rice-greengram sequence during 2015-16 and 2016-17 kharif and rabi seasons

\begin{tabular}{|c|c|c|c|c|c|c|}
\hline \multirow[t]{2}{*}{ Treatments } & \multicolumn{3}{|c|}{ 2015-16 } & \multicolumn{3}{|c|}{ 2016-17 } \\
\hline & $\begin{array}{c}\text { Rice } \\
\text { grain } \\
\text { yield } \\
\left(\mathrm{kg} \mathrm{ha}^{-1}\right)\end{array}$ & $\begin{array}{l}\text { Rice grain } \\
\text { equivalent } \\
\text { yield of } \\
\text { Greengram } \\
\left(\mathrm{kg} \mathrm{ha}^{-1}\right)\end{array}$ & $\begin{array}{c}\text { System } \\
\text { productivity } \\
\left(\mathrm{kg} \mathrm{ha}^{-1}\right)\end{array}$ & $\begin{array}{l}\text { Rice } \\
\text { grain } \\
\text { yield } \\
\left(\mathrm{kg} \mathrm{ha}^{-1}\right)\end{array}$ & $\begin{array}{l}\text { Rice grain } \\
\text { equivalent } \\
\text { yield of } \\
\text { Greengram } \\
\left(\mathrm{kg} \mathrm{ha}^{-1}\right)\end{array}$ & $\begin{array}{c}\text { System } \\
\text { productivity } \\
\left(\mathrm{kg} \mathrm{ha}^{-1}\right)\end{array}$ \\
\hline \multicolumn{7}{|c|}{ Crop establishment techniques } \\
\hline$M_{1}:$ DDS rice & 6194 & 2888 & 9082 & 6421 & 2718 & 9139 \\
\hline $\mathbf{M}_{2}:$ Aerobic rice & 5283 & 2924 & 8207 & 5645 & 2769 & 8414 \\
\hline $\begin{array}{r}M_{3}: \text { Planting } \\
\text { with machine }\end{array}$ & 6572 & 2659 & 9231 & 6954 & 2515 & 9469 \\
\hline $\begin{array}{l}\mathrm{M}_{4}: \text { Normal } \\
\text { planting }\end{array}$ & 6308 & 2850 & 9157 & 6636 & 2705 & 9341 \\
\hline SEm \pm & 147 & 51 & 143 & 155 & 50 & 166 \\
\hline $\mathrm{CD}(\mathrm{P}=\mathbf{0 . 0 5})$ & 508 & 177 & 495 & 536 & 173 & 574 \\
\hline CV\% & 9.3 & 7.1 & 6.2 & 9.4 & 7.2 & 7.1 \\
\hline \multicolumn{7}{|c|}{ Nitrogen levels (Kg ha ${ }^{-1}$ ) } \\
\hline N1: 90 & 4848 & 2605 & 7453 & 4947 & 2510 & 7457 \\
\hline $\mathrm{N} 2: 120$ & 5881 & 2708 & 8589 & 6262 & 2566 & 8806 \\
\hline N3:150 & 6409 & 2893 & 9302 & 6722 & 2700 & 9444 \\
\hline $\mathbf{N 4 : 1 8 0}$ & 6597 & 2935 & 9531 & 6984 & 2777 & 9761 \\
\hline N5:210 & 6713 & 3010 & 9723 & 7155 & 2831 & 9986 \\
\hline SEm \pm & 140 & 58 & 163 & 158 & 48 & 193 \\
\hline $\mathrm{CD}(\mathrm{P}=\mathbf{0 . 0 5})$ & 404 & 167 & 469 & 455 & 138 & 556 \\
\hline CV\% & 8.0 & 7.1 & 6.3 & 8.7 & 6.0 & 6.2 \\
\hline Interaction & NS & $\mathrm{NS}$ & NS & $\mathrm{NS}$ & NS & NS \\
\hline
\end{tabular}


Table.2 Economics of rice-greengram system as influenced by crop establishment techniques and nitrogen levels during 2015-16 and 2016-17

\begin{tabular}{|c|c|c|c|c|c|c|}
\hline \multirow[t]{2}{*}{ Treatments } & \multicolumn{3}{|c|}{ 2015-16 } & \multicolumn{3}{|c|}{ 2016-17 } \\
\hline & $\begin{array}{l}\text { Gross } \\
\text { returns } \\
(\text { Rs. ha-1) }\end{array}$ & $\begin{array}{c}\text { Net } \\
\text { returns } \\
\left(\text { Rs. ha- } \text { ha }^{-1}\right)\end{array}$ & $\begin{array}{c}\text { Return per } \\
\text { rupee } \\
\text { investment }\end{array}$ & $\begin{array}{l}\text { Gross } \\
\text { returns } \\
\left.\left(\text { Rs. }^{-1}\right)^{-1}\right)\end{array}$ & $\begin{array}{c}\text { Net } \\
\text { returns } \\
\left(\text { Rs. }^{-1} \mathbf{h a}^{-1}\right)\end{array}$ & $\begin{array}{l}\text { Return per } \\
\text { rupee } \\
\text { investment }\end{array}$ \\
\hline \multicolumn{7}{|c|}{ Crop establishment Techniques } \\
\hline$M_{1}:$ DDS rice & 140768 & 85447 & 2.89 & 146311 & 88580 & 2.92 \\
\hline $\mathbf{M}_{2}:$ Aerobic rice & 127293 & 71372 & 2.53 & 134690 & 76360 & 2.61 \\
\hline $\begin{array}{l}M_{3}: \text { Planting with } \\
\text { machine }\end{array}$ & 143266 & 78870 & 2.35 & 151895 & 84589 & 2.40 \\
\hline $\mathbf{M}_{4}:$ Normal planting & 141962 & 77241 & 2.38 & 149588 & 81957 & 2.44 \\
\hline SEm \pm & 2197 & 2197 & 0.03 & 2568 & 2569 & 0.07 \\
\hline $\mathrm{CD}(\mathrm{P}=\mathbf{0 . 0 5})$ & 7604 & 7604 & 0.12 & 8889 & 8889 & 0.26 \\
\hline CV\% & 6.2 & 10.9 & 5.3 & 6.8 & 12.0 & 11.7 \\
\hline \multicolumn{7}{|l|}{ Nitrogen levels $\left(\mathrm{Kg} \mathrm{ha}^{-1}\right)$} \\
\hline N1: 90 & 115635 & 56270 & 2.03 & 119685 & 57714 & 1.96 \\
\hline N2:120 & 133319 & 73592 & 2.49 & 141070 & 78709 & 2.46 \\
\hline N3:150 & 144197 & 84107 & 2.82 & 151212 & 88463 & 2.73 \\
\hline N4:180 & 147759 & 87307 & 2.90 & 156256 & 93118 & 2.86 \\
\hline N5:210 & 150702 & 89887 & 2.98 & 159881 & 96354 & 2.94 \\
\hline SEm \pm & 2445 & 2445 & 0.08 & 2541 & 2542 & 0.06 \\
\hline $\mathrm{CD}(\mathrm{P}=0.05)$ & 7042 & 7041 & 0.23 & 7322 & 7323 & 0.19 \\
\hline CV\% & 6.1 & 10.8 & 11.1 & 6.1 & 10.6 & 8.6 \\
\hline Interaction & NS & NS & NS & NS & NS & NS \\
\hline
\end{tabular}

Price of Rice : Rs.14,600 per tonne in 2015-16 and Rs.15,100 in 2016-17

Price of Rice straw: Rs. 1000 per tonne in 2015-16 and 2016-17

Price of Greengram: Rs. 48,500 per tonne in 2015-16 and Rs.52, 250 in 2016-17

Price of green gram haulm: Rs. 500 per tonne in 2015-16 and 2016-17

Maximum value of net returns was recorded with DDS rice-greengram system (85447, 88580 Rs. ha ${ }^{-1}$ during 2015-16 and 2016-17 respectively) which was followed by planting with machine -greengram system. The lowest values of net returns was observed with aerobic rice-greengram system $(71372,76360$ Rs.ha $^{-1}$ during 2015-16 and 2016-17 respectively). The return per rupee investment was the highest with DDS rice-greengram system (2.89,2.92during 2015-16 and 2016-17 respectively) followed by planting with machine -greengram system and normal planting-greengram system. The lowest returns per rupee investment were observed with aerobic rice-greengram system (2.53, 2.61during 2015-16 and 2016-17 respectively). These results are in agreement with that of Rao et al., (2016) who reported that though the gross returns were higher with machine planting, net returns and $\mathrm{B}: \mathrm{C}$ ratio was higher with DDS system due to conspicuously lesser cost of cultivation of DDS rice compared to other establishment systems. Increased levels of $\mathrm{N}$ application to rice increased gross returns, net returns and return per rupee investment in rice-greengram system and the maximum values were recorded with application of $210 \mathrm{Kg} \mathrm{N} \mathrm{ha}^{-1}$ (Table.2). 


\section{References}

Mankotia, B.S., Sekhar, J and Negi, S.C. 2009. Effect of crop establishment techniques on productivity of rice-wheat cropping system. Oryza. 46 (3): 205208.

Ministry of Agriculture, Government of India. 2016-17. https://www.indiastat.com/default.aspx

Murthy, K.V.R., Rao, A.U and Visalakshmi, V. 2015. Influence of rice establishment systems on the productivity of ricepulse system in North Coastal Zone of Andhra Pradesh. (In) Abstract of papers. International Rice Symposium held From 18-20 November 2015 at Hyderabad. pp. 443.

Rao, A.U., Visalakashmi, V., Kumar K.M and
Rao, N.V.G. 2016. Evaluation of establishment methods and nitrogen management in rice. (In) Extended summaries of $4^{\text {th }}$ International Agronomy Congress, held during November, 22-26, 2016, at New Delhi, India. pp. 1188.

Sanjay, M.T., Setty, T.K.P and Nanjappa, H.V. 2006a. Productivity, energetics and economics of different systems of crop establishment in rice. Crop Research. 31 (3): 350-353.

Sridhara, C.J., Ramachandrappa, B.K., Kumarswamy, A.S and Gurumurthy, K.T. 2011. Effect of genotypes, planting geometry and methods of establishment on root traits and yield of aerobic rice. Karnataka Journal of Agricultural Sciences. 24 (2): 129-132.

\section{How to cite this article:}

Amara Jyothi. P., M. Martin Luther, A. Upendra Rao and Mounika. B. 2020. Effect of Crop Establishment Techniques and N Levels of Rice on System Productivity and Economics of Rice- Greengram System. Int.J.Curr.Microbiol.App.Sci. 9(06): 487-493. doi: https://doi.org/10.20546/ijcmas.2020.906.063 